\title{
ERRATUM
}

Genes \& Development 31: 1509-1528 (2017)

\section{Erratum: RNA-binding proteins in neurodegeneration: mechanisms in aggregate}

Erin G. Conlon and James L. Manley

In the abstract of the above-mentioned review, due to an editing error, the sentence, "Here we synthesize the progress made at the clinical, genetic, and biophysical levels and conclude that this review offers the most parsimonious explanation for these mysterious diseases" is incorrect. It should read, "Here we synthesize the progress made at the clinical, genetic, and biophysical levels and conclude that this perspective offers the most parsimonious explanation for these mysterious diseases." This has been corrected online.

We apologize for any confusion this error may have caused.

doi: $10.1101 / \operatorname{gad} .308205 .117$ 


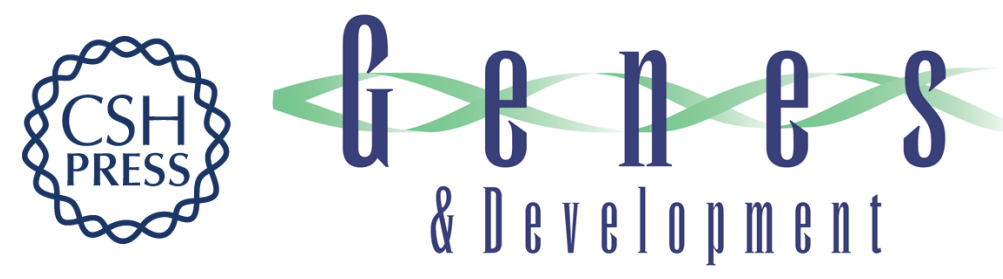

\section{Erratum: RNA-binding proteins in neurodegeneration: mechanisms in aggregate}

Erin G. Conlon and James L. Manley

Genes Dev. 2017, 31:

Access the most recent version at doi:10.1101/gad.308205.117

Related Content RNA-binding proteins in neurodegeneration: mechanisms in aggregate

Erin G. Conlon and James L. Manley

Genes Dev. August , 2017 31: 1509-1528

\section{License}

Email Alerting

Receive free email alerts when new articles cite this article - sign up in the box at the top

Service right corner of the article or click here.

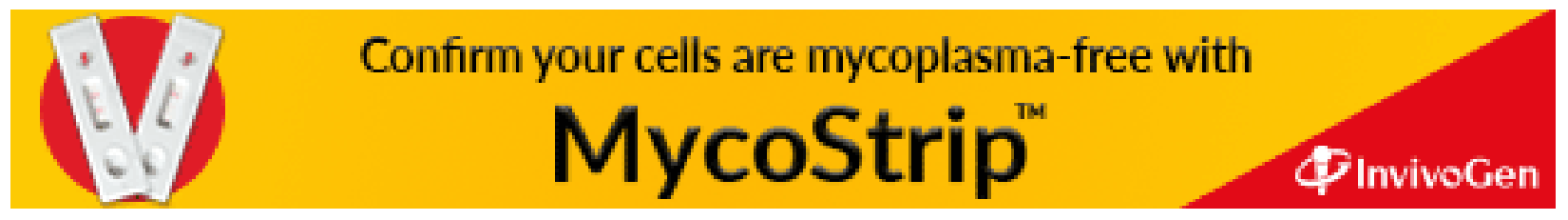

